\title{
Relationship of Self-control and Media Exposure with Premarital Sexual Behaviour in Senior High School Students
}

\section{Nada Adinda Safira Amin, Hartati Eko Wardani, and Rany Ekawati}

Department of Public Health, Faculty of Sport Science, Universitas Negeri Malang, Malang, East Java, Indonesia

\section{ORCID:}

Rany Ekawati: https://orcid.org/0000-0003-2883-1191

Hartati Eko Wardani: https://orcid.org/0000-0002-6748-2556

\section{Abstract}

Premarital sexual behaviour is a social phenomenon that is common today. Modernization is one of the reasons for various parties to share pornographic behaviour on the pretext of being a medium for sexual knowledge. Adolescents with good self-control will be able to control negative behavioural impulses from external factors such as premarital sexual behaviour. This study aims to determine the relationship of self-control and media exposure with premarital sexual behaviour in 11th-grade students of Senior High School " $X$ " in Malang City. The study utilized a correlational quantitative method with a cross-sectional design. A total of 76 students, selected using a simple random sampling technique, were included in the study. Data were collected through a questionnaire and analysed using a linear regression analysis with a significance level of $(\alpha=5 \%)=0.05$. The study found that self-control and information media were both partially and simultaneously related to the premarital sexual behaviour in adolescents. Based on the analysis, the beta value of the selfcontrol was $\beta=0.303$, and that of the information media was $\beta=0.227$. This indicated that the self-control variable had the most dominant relationship with premarital sexual behaviour. Further, the R-Square value was 0.416, which meant premarital sexual behaviour in $41.6 \%$ of the 11th-grade adolescents of Senior High School "X" in Malang City was related to two independent variables, self-control and information media.

Keywords: adolescent, self-control, media exposure, premarital sexual behaviour.

Selection and Peer-review under the responsibility of the ISMoPHS 2020 Conference Committee.

\section{Introduction}

Premarital sexual behaviour is driven by sexual desire, whether done alone, with the opposite sex or the same sex without any marital ties [1]. Hurlock explained about the stages of premarital sexual behaviour, namely from the pattern of intimacy during dating which can end in premarital sexual behaviour starting from kissing, light making out, heavy making out, and then intimate relationships. Initially dry kissing, wet kissing, 
kissing the neck (necking), after that rubbing the genitals (petting), trying to rub the penis against the lips of the vagina and so on until intercourse [2].

Based on the results of the 2010 population census, the population of Indonesian adolescents aged 10-19 is 43.5 million people. The number of teenagers in the world is 1.2 billion of the world's population [3]. Self-control is a person's ability to organize, guide, regulate and control all behaviour for a positive impact [4]. Several studies have reported that the existence of good self-control can be used as a protective factor for adolescents towards a more positive life [5]. On the other hand, in several studies, adolescents with low levels of self-control showed higher risk-taking behaviour and tended toward risky sexual behaviour in adolescents [6].

There are various consequences due to problems with premarital sexual behaviour by adolescents, from unwanted pregnancy and sexually transmitted diseases. Modernization is one of the reasons by various parties to spread pornographic on the pretext of being a medium for sexual knowledge. Starting from print media such as books and magazines containing pornographic contexts and electronic media such as the internet (social media) and pornographic films made as an excuse for sexual education so that adolescents who enter the age with a high sense of sexual knowledge will be easily affected by stimuli that are proactive and too indulgent. As a result of exposure to pornographic media that is too proactive, adolescents can be aroused to have premarital sexual relations due to support from various media that contain pornographic contexts [1]. According to Indonesian Youth Statistics data, adolescents with the age group 16-18 years are the highest age group who access the internet compared to other age groups with a percentage of $78.90 \%$. This data explains that adolescents are closely related to information media, especially internet-type media [7]. Research and Development for Health and UNESCO reported that 56\% of Indonesian adolescents have had premarital sex. As for other results, Indonesian teenagers who have been exposed to pornography are $96.7 \%$ and addicted to pornography as much as 3.7\% [8].

Malang is an area in East Java with the second highest prevalence rate after Surabaya which has HIV / AIDS cases with 890 HIV / AIDS cases [9]. Then according to KPA (AIDS Prevention Commission) data at the Malang City Health Office in the 2018 Malang City HIV case report there were 1,165 cases with the highest incidence spread in Blimbing District, namely 307 cases, then Lowokwaru District 251 cases, Sukun 243 cases, Klojen 200 cases, and Kedungkandang 164 cases. Based on an interview with the Sektap (Permanent Secretariat) of KPA Malang City, data on HIV cases with specific age levels cannot be disseminated because it is the privacy of the patient. However, the Sektap 
KPA of Malang City explained that the highest data on HIV cases in Malang City with the level of adolescence (high school students) was in Lowokwaru District [10].

\section{Material and Method}

This study aims to see how the relationship between self-control and exposure information media with premarital sexual behaviour of adolescents class XI senior high school " $X$ 'in Malang City. This research is correlational quantitative observational with cross sectional research design. In taking the sample, this study used simple random sampling technique. Samples obtained was 76 students. The instrument used was a questionnaire. Analysis uses linear regression. This research has passed the ethical test by the Health Research Ethics Committee of the University of Muhammadiyah Malang.

\section{Results}

Table 1 contains the characteristics of the respondents. Characteristics of respondents was found that dominant was female 53 students (69.7\%), the dominant age of the respondents was 17 years old 39 students (51.3\%) and a total of 76 respondents (100\%) were Muslim.

TABLE 1: Characteristics respondents.

\begin{tabular}{|l|l|c|c|}
\begin{tabular}{l} 
No. \\
\hline 1
\end{tabular} & Characteristics & $\boldsymbol{n}$ & $\%$ \\
\hline & Sex & & \\
\hline & Goy & 23 & 30.3 \\
\hline 2 & Age (yr) & 53 & 69.7 \\
\hline & 15 & & \\
\hline 16 & 1 & 1.3 \\
\hline 3 & Religion & 36 & 47.4 \\
\hline & Muslim & 39 & 51.3 \\
\hline Source: Author's own work. & 76 & 100 \\
\hline
\end{tabular}

Table 2 contains respondents answer for questionnaire. Respondents' more dominant self-control was self-control at a moderate level with a frequency of 42 students (55.3\%), and the dominant exposure to information media was exposure to information media at a moderate level with 34 students (44.7\%) then premarital sexual behaviour of adolescents. the dominant one was premarital sexual behaviour at a low level with 68 students (89.5\%). 
TABLE 2: Respondents' answer about questionnaire.

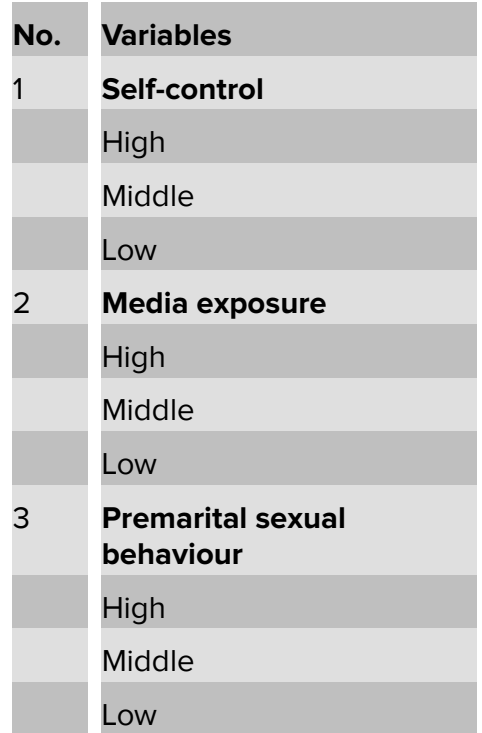

Source: Author's own work.

\begin{tabular}{|c|c|}
\hline$n$ & $\%$ \\
\hline 14 & 18.4 \\
\hline 42 & 55.3 \\
\hline 20 & 26.3 \\
\hline & \\
\hline 12 & 15.8 \\
\hline 34 & 44.7 \\
\hline 30 & 39.5 \\
\hline & \\
\hline 1 & 1.3 \\
\hline 7 & 9.2 \\
\hline 68 & 89.5 \\
\hline
\end{tabular}

89.5

Bivariate analysis showed that the correlation between self-control and premarital sexual behaviour ( $r=0.521$ ) was categorized as moderate, as well as the correlation between media exposure and premarital sexual behaviour ( $r=0.456)$ (Table 3.).

TABLE 3: Result of bivariate analysis.

\begin{tabular}{l|l} 
No. & Variables \\
\hline 1 & Self-control \\
\hline 2 & Media exposure \\
\hline *Pearson & correlation
\end{tabular}

*Pearson correlation

Source: Author's own work.

\begin{tabular}{|c|c|}
\hline Sig & $\boldsymbol{r}$ \\
\hline $0.004^{*}$ & 0.521 \\
\hline $0.11^{*}$ & 0.456 \\
\hline
\end{tabular}

The result of multiple regression linear analysis showed that self-control and media exposure persisted in the final model as predictor of premarital sexual behaviour ( $p$ value $<0.05)$. It could be seen in Table 4.

TABLE 4: Result of regression linear.

\begin{tabular}{|l|c|c|c|c|c|c|}
\hline \multicolumn{1}{|c|}{ Model } & \multicolumn{2}{|c|}{ Unstandardized Coefficients } & $\begin{array}{c}\text { Standardized } \\
\text { Coefficients }\end{array}$ & t & Sig. & R square \\
\hline & B & Std. Error & Beta & & \\
\hline & (Constant) & 20.965 & 8.490 & & 2.469 & 0.016 \\
\hline Self-control & 0.196 & 0.070 & 0.303 & 2.802 & 0.006 & 0.416 \\
\hline Media exposure & 0.395 & 0.188 & 0.227 & 2.103 & 0.039 & \\
\hline
\end{tabular}

Source: Author's own work. 


\section{Discussion}

The relationship between information media and adolescent premarital sexual behaviour shows that the results of bivariate analysis on the Pearson correlation test resulted in a value of $p=0.011<0.05$, which means that there is a significant correlation between information media and premarital sexual behaviour. The analysis table also shows the value of $r=0.456$, which means that $r$ lies between $0.51-0.75$ which states that the degree of relationship between information media and premarital sexual behaviour is moderate.

Hypothesis test on the partial test ( $t$ test) obtained the significance value of the relationship is $0.039<0.05$, which means that the information media partially has a significant relationship with premarital sexual behaviour in adolescents. There is a relationship between information media and premarital sexual behaviour among adolescents.

Another research has same findings that there is a relationship between exposure to information media and adolescent sexual behaviour at high school students, the results of the analysis stated that 59 students of the total respondents who were exposed to pornographic media tended to engage in risky sexual behaviour [11]. Another research found similar, there was a relationship between mass media exposure and premarital sex behaviour of class $X$ adolescents at SMA Muhammadiyah 2 Tangerang [12].

The simultaneous relationship between information media and information media with premarital sexual behaviour of adolescents based on the results of multivariate analysis using multiple linear regression test results obtained a beta value of $\beta=0.303$ for self-control variables and $\beta=0.277$ for information media variables, seen from the beta value of self-control variables. greater than the beta value of the information media variable which indicates the self-control variable has the most dominant relationship with the dependent variable.

Based on the above statement which explains that the self-control variable is the variable that has the most dominant relationship with the dependent variable, this is supported by another research which found that adolescents with the ability to control their sexual desires tend to have positive behaviour and are not easily influenced by external factors [13]. For example, a teenager with good self-control will not kiss until they have sex (sexual intercourse) during courtship.

Then the hypothesis testing on the $F$ test resulted in a significance value of the relationship was $0.002<0.05$, which means that simultaneous self-control has a significant relationship with premarital sexual behaviour in adolescents class XI SMA " $X$ " in 
Malang City. There is a correlation between self-control and premarital sexual behaviour in adolescents. Furthermore, from the determination coefficient test, it is known that the value of R-Square is 0.416 . This means that $41.6 \%$ of premarital sexual behaviour among adolescents is related to the two independent variables, namely self-control and information media. Adolescents are related to several factors that become the reasons for adolescents to commit sexual behaviour. self-control regarding sexuality because of the perceived sexual urge [14]. Self-control attitudes and premarital sexual behaviour has significant correlation [15].

\section{Conclusion}

There is a strong relationship between self-control and premarital sexual behaviour partially, and there is a moderate relationship between information media and premarital sexual behaviour, and at the simultaneous level of relationship the two independent variables have a simultaneous relationship with the dependent variable, and self-control is the independent variable which has a dominant relationship with the dependent variable. Then the percentage of the relationship between the independent variable and the dependent variable is 0.416 , which means that $41.6 \%$ of the premarital sexual behaviour of adolescents is related to the two independent variables and $58.4 \%$ is related to other variables not examined. Government can activate PKPR (Youth Care Health Service) in schools that have not implemented and activate a system of restricting access to pornographic content for children under legal age. The school can add education about adolescent reproductive health and the dangers of premarital sexual behaviour so that adolescents are more alert and take care of themselves. Academics and science can carry out further research in terms of premarital sexual behaviour of adolescents with more independent variables to obtain a more real phenomenon and picture related to adolescent premarital sexual behaviour. For students, it can increase religiosity, get closer to God so that they are not easily tempted and maintain and improve self-control that is already in themselves, also divert free time to their hobbies and focus more on the study that is being undertaken.

\section{Ackowledgment}

None 


\section{Conflict of Interest}

There is no conflict of interest.

\section{References}

[1] Hutama, J. P., Karyani, U. (2016). Hubungan Antara Kontrol Diri dengan Perilaku Seks Bebas pada Remaja. Surakarta: Universitas Muhammadiyah Surakarta.

[2] Alfiyah, N., Solehati, T. and Sutini, T. (2018). Gambaran Faktor-Faktor yang Berhubungan dengan Perilaku Seksual Pranikah pada Remaja SMP. Jurnal Pendidikan Keperawatan Indonesia, vol. 4, issue 2, pp. 131-9.

[3] WHO. (2014). WHO Calls for Stronger Focus on Adolescent Health. Retrieved from https://www.who.int/mediacentre/news/releases/2014/focus-adolescent-health/en/.

[4] Ghufron, M. N. and Risnawati, R. (2010). Teori-Teori Psikologi. Jogjakarta: Ar-Ruzz Media Group.

[5] Peviani, K. M., et al. (2019). Intergenerational Transmission of Delay Discounting: The Mediating Role of Household Chaos. Journal of Adolescent, issue 72, pp. 83-90.

[6] Quinn, P. D. and Fromme, K. (2010). Self-Regulation as a Protective Factor against Risky Drinking and Sexual Behavior. Psychology of Addictive Behaviors., vol. 24, issue 3, pp. 376-85.

[7] BPS. (2017). Statistik Pemuda Indonesia 2017. Jakarta. Badan Pusat Statistik.

[8] BKKBN. (2017). Laporan SDKI 2017 Remaja. Jakarta: BKKBN.

[9] BPS. (2017). Jumlah Kasus Penyakit Menurut Kabupaten/Kota dan Jenis Penyakit di Provinsi Jawa Timur, 2018. Retrieved from https://jatim.bps.go.id/statictable/2019/ 10/09/1674/jumlah-kasus-penyakit-menurut-kabupaten-kota-dan-jenis-penyakit-diprovinsi-jawa-timur-2018-.html.

[10] Dinas Kesehatan Kota Malang. (2018). Laporan Kasus HIV Kota Malang Tahun 2018. Malang: Dinkes Kota Malang.

[11] Dana, R. R. and Wijayanti, A. C. (2017). Menganalisis Tingkat Pengetahuan, Sikap, Dan Paparan Media Informasi Terhadap Perilaku Seksual Remaja Di SMP N 2 Mojosongo Boyolali. Surakarta: Universitas Muhammadiyah Surakarta.

[12] Purnomo, S. T. and Mustikawati, I. S. (2014). Hubungan Pengetahuan dan Keterpaparan Media dengan Perilaku Seks Pranikah Remaja di SMA Muhammadiyah 2 Tangerang. Indonesian of Health Information Management Journal, vol. 2, issue 1, pp. 30-9. 
[13] Istiqomah, N. and Notobroto, H. B. (2016). Pengaruh Kontrol Diri Terhadap Perilaku Seks Bebas Pranikah pada Remaja SMK "KTT" di Surabaya. Surabaya: Universitas Airlangga.

[14] Sya'diyah, H. (2019). Hubungan Antara Kontrol Diri Dengan Perilaku Seksual pada Remaja di Kota Pariaman. Riset Aktual Psikologi Universitas Negeri Padang, issue 4, pp. 1-11.

[15] Novandra, A. S. and Puspitasari, N. (2017). Hubungan Sikap Pengendalian Diri Dalam Penggunaan Media Jejaring Sosial Facebook Dengan Perilaku Seksual Pranikah Remaja Usia 15-19 Tahun (Studi Di Kelurahan Kapasmadya Baru Kecamatan Tambaksari Kota Surabaya). The Indonesian Journal of Public Health, vol. 12, issue 1, pp. 85-96. 